\title{
Article
}

\section{Realising, Adapting, and Thriving in Career Transitions from Gymnastics to Contemporary Circus Arts}

\author{
van Rens, Fleur E.C.A. and Filho, Edson \\ Available at http://clok.uclan.ac.uk/25958/ \\ van Rens, Fleur E.C.A. and Filho, Edson ORCID: 0000-0002-8548-4651 (2019) \\ Realising, Adapting, and Thriving in Career Transitions from Gymnastics to \\ Contemporary Circus Arts. Journal of Clinical Sport Psychology . ISSN 1932- \\ 9261
}

It is advisable to refer to the publisher's version if you intend to cite from the work. http://dx.doi.org/10.1123/jicsp.2018-0075

For more information about UCLan's research in this area go to http://www.uclan.ac.uk/researchgroups/ and search for <name of research Group>.

For information about Research generally at UCLan please go to http://www.uclan.ac.uk/research/

All outputs in CLoK are protected by Intellectual Property Rights law, including Copyright law. Copyright, IPR and Moral Rights for the works on this site are retained by the individual authors and/or other copyright owners. Terms and conditions for use of this material are defined in the policies page.

\section{CLoK}

Central Lancashire online Knowledge www.clok.uclan.ac.uk

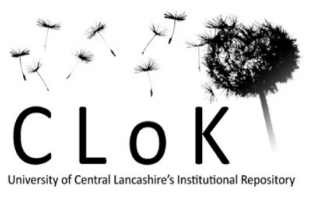


Table 1

Themes associated with Realising, Adapting, and Thriving in Career Transitions from Gymnastics to Professional Circus

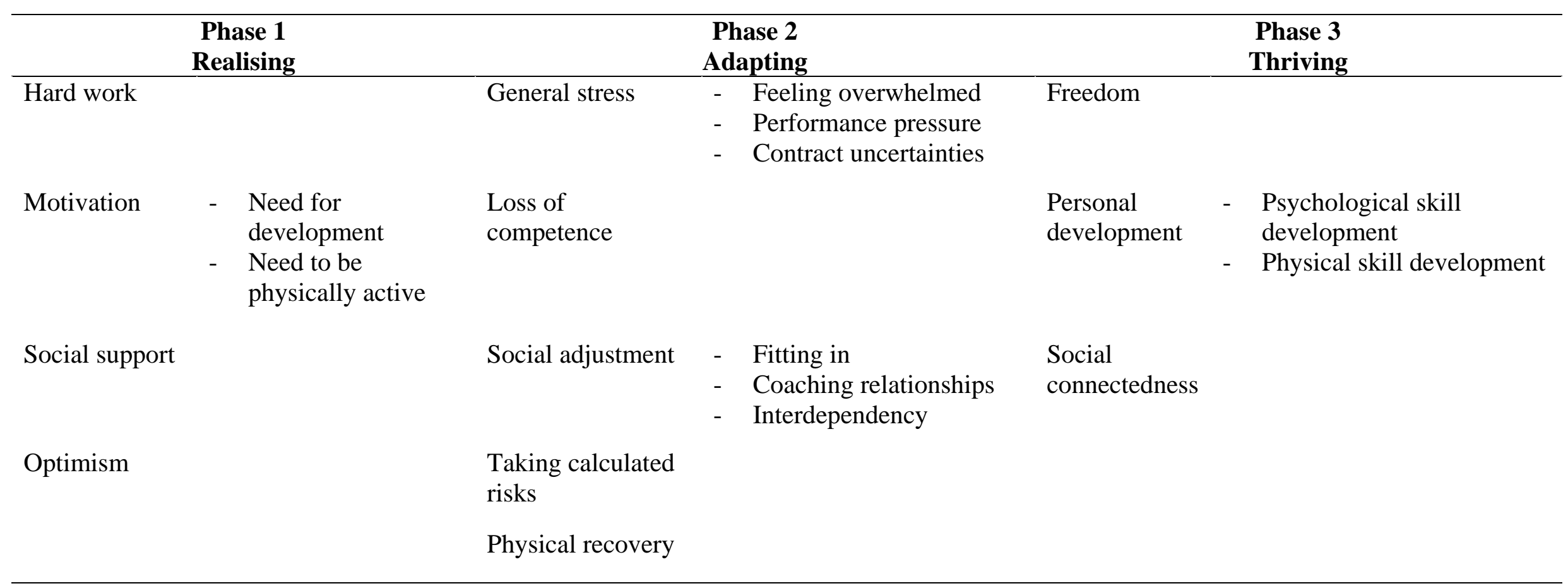

